\title{
A note on the term 'lithic'
}

\author{
George (Rip) Rapp \\ Department of Geological Sciences, University of Minnesota, Duluth and Twin Cities, U.S.A. \\ Email: grapp@d.umn.edu
}

\begin{abstract}
:
The term 'lithic' is derived from the ancient Greek word for 'rock' (lithos), used in the late fourth century BCE by the scholar Theophrastus. The term 'lithic' in the way we use it today, meaning small rock artifact, most often chipped or ground stone, came into common use less than eight decades ago. The terms 'stone tool' and 'stone implement' remain firmly entrenched in the archaeological literature.
\end{abstract}

Keywords: lithic; terminology; etymology

It is well known that the term 'lithic' derives from the Greek word for 'rock': lithos ( $\lambda i \theta o \varsigma)$. In his treatise On Stones ( $\Pi \varepsilon \rho \imath \Lambda \imath \theta \omega v)$, which remained the definitive reference through the Middle Ages, Theophrastus (circa 371-287 BCE) discussed the properties of minerals, gems, rocks, and mineral earths. The only worked stones he mentioned are seal stones, gems, and rocks used in monuments and buildings. This book is the earliest known scientific work dealing with rocks and minerals, and it put the term 'lith' into the literature. For the Greek text, English translation, and commentary of this work see Caley \& Richards (1956).

In the first century CE Pliny (23-79 CE) in his monumental work Natural History discussed only building stones, including small fragments for tessellated floors, and gems. At the very end of the Middle Ages, Georgius Agricola (1494-1555), often called "the father of mineralogy", published his De Natura Fossilium (now frequently referred to as Textbook of Mineralogy). For a recent translation by M. C. Bandy and J.A. Bandy see Agricola (2004). This book is the best source of what was known about minerals, gems, and some rocks in the late Middle Ages. The major value for lithic studies is what it tells about the rocks and minerals worked into gem material. The Bandy translation from the Latin does not use the term 'lithic(s)'. The Latin terms for 'rocks' were lapideus and lapidarius. I am not aware of any separate Latin term for 'rock artifact'.

Ancient and modern Greek both have a second term for 'rock': petra $(\pi \varepsilon \tau \rho \alpha)$. This is the term in common use in Greece today. I spent seven years as associate director of the excavation at Nichoria in southwestern Greece and another seven directing coastal change projects in Greece. All the Greeks involved with these projects used the term petra for both

Published by the School of History, Classics and Archaeology, University of Edinburgh ISSN: 2055-0472. URL: http://journals.ed.ac.uk/lithicstudies/

This work is licensed under a Creative Commons Attribution 2.5 UK: Scotland License. 
geologic rocks and the lithology of stone artifacts. The widely used modern English-Greek and Greek-English dictionary (Divry 1969) lists both $\lambda i \theta o \varsigma$ and $\pi \varepsilon \tau \rho \alpha$ for 'stone'.

In modern times the word for geologic rock in German is stein, in French it is roche, and in Spanish it is piedra (also used specifically for flint). For our term 'lithic', German seems to have nothing that quite corresponds, the French have lithique and pierre, and the Spanish have lithica.

The root 'lith' has been used to form many related terms: lithology, lithified, lithosphere, lithophile, lithofacies, and lithography (the process of printing from a flat stone). A host of other geologic terms also include 'lithic' as a prefix or an adjective, e.g., lithic arkose, lithic tuff, and lithic wacke. The term also occurs in archaeological period names such as 'Paleolithic' and 'Neolithic'.

One might trace the development of the word lithic by consulting dictionaries through time. The first comprehensive English dictionary was that of Samuel Johnson (1818) which described the root 'lith' only in relation to physiology as a joint or limb, and this use was listed as obsolete. The words 'litharge' ( $\mathrm{PbO}$ ) and 'lithography' were listed. The most detailed dictionary is the Oxford English Dictionary (1933), compiled between 1878 and 1928. It also defines 'lith' as used in biology and physiology as pertaining to stone (e.g., calculi in the bladder). In terms of archaeology it lists 'Lithic Age', the 'Stone Age', but says nothing about artifacts.

Interestingly, Webster's New World College Dictionary (2000) lists 'lithic' as a geologic adjective but does not mention any archaeological use. The comprehensive Glossary of Geology (Jackson 1997) does define 'lithic' as an archaeological noun (chipped or ground stone) and as an adjective pertaining to stone artifacts. In the interest of full disclosure, I wrote the definitions of these terms for the Glossary. In a relevant encyclopedia defining archaeological concepts and terms (Gibbon 1998) the only mention of 'lithic' is under the title Lithic Technology (Paleoindian). This article covers only the process by which stone was intentionally modified to produce tools, weapons, and other objects; nothing is said about properties, sources, or other aspects of lithics.

Turning to archaeology and archaeological geology, in his iconic Geological Evidences for the Antiquity of Man, first published in 1863, Lyell (1797-1875) called all stone artifacts 'flints' (Lyell 1870, the edition I have). In modern terms 'flint' may be the proper term for lithics from southeastern England, but the word is questionable when used generically for all high silica rocks of chemical sedimentary origin (e.g., chert and chalcedony). In the nineteenth and early twentieth centuries stone artifacts were routinely called 'flints' (e.g., Petrie 1926). I have examined many stone tools from Greece, Cyprus, Turkey, Israel, Egypt, and North America, and I would not call many of them flint. Perhaps my definition may be too narrow.

In Troy and Its Remains Schliemann (1875, reprint 1976) used the term 'stone implements' or used the specific geologic rock name, e.g., agate, diorite, mica-schist, when referring to lithic artifacts. The word 'lithic(s)' does not occur. This work was translated from the German by Philip Smith. I have not seen the original German text. William Henry Holmes (1846-1933) was one of the first Americans to do comprehensive studies of lithics (Holmes 1894, 1897). He used the term 'stone implements'. Raphael Pumpelly, an American geologist who excavated the ancient site of Annu in Turkestan used the term 'stone implements' (Pumpelly 1908). The Swedish geologist Johan Gunnar Andersson who worked in China from 1914-1924 (see Rapp 2014) and who uncovered and defined the Chinese Neolithic and discovered the 'Peking Man' site used the term 'stone implement' in his publications (e.g., Andersson 1943).

Through the first third of the twentieth century I can find no use of the term 'lithic' in the archaeological literature. The first use I am aware of is in the Indiana Academy of Science 
Proceedings (Guernsey 1937). The first papers in American Antiquity to use the term were Shippee (1948) and Goggin (1950). Since the 1970s use of the term 'lithic' has grown explosively. The book Archaeomineralogy (Rapp 2009) devotes one chapter (IV) to Lithic Materials. This chapter covers all major lithological materials that have been used to make implements since the Paleolithic. Since the 1950s the word 'lithic' has been appearing in the titles of archaeological articles in America but more slowly overseas. Excavation volumes recording projects in the Old World (Greece, Turkey, Israel, Cyprus, Egypt, and England) almost invariably still use 'stone tools', 'stone implements', etc.

Although the terms 'stone tool' and 'stone implement' have remained in common use, the term 'lithic' has seen explosive growth. As seen above, the term 'lithic', as we use it, is of relatively recent origin. If the incorporation of the term 'lithic' into the nomenclature of archaeology happens before the definition gets too muddy, it will be a positive development. So far there seems to be a consensus in the literature about its meaning, but lithic studies need to delineate the boundaries of the definition. It seems obvious that neither a stone monument nor an antler tool is a lithic. Stone tools, implements, hammer stones, and vessels qualify as lithics, but stone beads and seal stones may not have achieved a consensus.

\section{Acknowledgements}

This article was reviewed in manuscript form by Christopher Hill (an archaeologist and geoarchaeologist), Lucy Wilson (a lithics specialist), and Nancy Nelson (an editor with a geologic background). I thank them for their wise and helpful comments

\section{References}

anonymous. Oxford English Dictionary. 1933, Oxford University Press: Glasgow, etc. In multiple volumes.

anonymous. Webster's New World College Dictionary. Fourth Edition. 2000, IDG Books, Foster City, CA.

Agricola, G. 2004, De Natura Fossilium (Textbook of Mineralogy). Translated from the first Latin Edition of 1546 by M. C. Bandy and J.A. Bandy. Dover Publications, Mineola NY, $240 \mathrm{p}$.

Andersson, J.G. 1943, Researches Into the Prehistory of the Chinese. Bulletin 15. The Museum of Far Eastern Antiquities, Stockholm, 304 p. plus 200 plates.

Caley, E. \& Richards, J. 1956, Theophrastus On Stones: Introduction, Greek Text, English Translation, and Commentary. Ohio State University, Columbus, 238 p.

Divry, G. 1969, Divry's New English-Greek and Greek-English Handy Dictionary. D.C. Divry, Inc., New York, 511 p.

Gibbon, G. 1998, Archaeology of Prehistoric North America: An Encyclopedia. Garland Publishing, New York and London, 941 p.

Goggin, J. 1950, An Early Lithic Complex from Central Florida. American Antiquity, 16(1):46-49. Stable URL: http://www.jstor.org/stable/276339

Guernsey, E. 1937, Certain southern Indiana sources of lithic artifact material. Indiana Academy of Science Proceedings, 46:47-52. 
Holmes, W.H. 1894, Natural History of Flaked Stone Implements. Memoirs, International Congress of Anthropology, Chicago, 1894, p. 120-139.

Holmes, W.H. 1897, Stone Implements of the Potomac-Chesapeake Tidewater Province. Fifteenth Annual Report, Bureau of Ethnology, 1893-1894, p. 13-152.

Jackson, J. 1997, Glossary of Geology. Fourth Edition. American Geological Institute, Alexandria, VA, 769 p.

Johnson, S. 1818, Dictionary of the English Language. In Four Volumes. Longman, Hurst, Rees, Orme, and Brown, London.

Lyell, C. 1870, Geological Evidences for the Antiquity of Man. Second American Edition. Lippincott \& Co, Philadelphia, 526 p.

Petrie, W.F. 1926, Observations on "The Recent Geology and Neolithic Industry of the Northern Fayum Desert" by Miss E.W. Gardner and Miss G. Caton-Thompson, F.R.G.S. The Journal of the Royal Anthropological Institute of Great Britain and Ireland, 56:325-327. http://www.jstor.org/stable/2843615

Pumpelly, R. 1908, Explorations in Turkestan. Expedition of 1904, Prehistoric Civilization of Апnи. In Two Volumes. Carnegie Institution of Washington, Washington D.C.

Rapp, G. 2009, Archaeomineralogy. Springer-Verlag. Berlin \& Heidelberg, 348 p. doi:10.1007/978-3-540-78594-1

Rapp, G. 2014 (in press), Johan Gunnar Andersson: Archaeological Geologist and Pioneer. Earth Sciences History 33 No. 1.

Schliemann, H. 1976, Reprint of 1875 Edition. Troy and Its Remains. Arno Press, New York, 392 p. plus 3 maps and 52 plates, 1716 p.

Shippee, J. 1948, Nebo Hill, a lithic complex in western Missouri. American Antiquity, 14(1):29-32. doi: $10.2307 / 276040$ 